\title{
An outbreak of cutaneous anthrax in a non-endemic district - Visakhapatnam in Andhra Pradesh
}

\author{
G. Raghu Rama Rao, Jyothi Padmaja, M. K. Lalitha*, P. V. Krishna Rao, K. V. T. Gopal, \\ Hari Kishan Y. Kumar, Promila Mohanraj* \\ Departments of Dermatology and Microbiology, Andhra Medical College, Visakhapatnam, *Department of Clinical Microbiology, Christian \\ Medical College, Vellore, India
}

Address for correspondence: Dr. G. Raghu Rama Rao, Professor and Head, Dept of Dermatology, Gopal Sadan, D. No: 15-1-2C, Naoraji Road, Maharanipeta, Visakhapatnam - 530002, India. E-mail: graghuramarao@hotmail.com

\section{ABSTRACT}

Background: Anthrax is a disease of herbivorous animals, and humans incidentally acquire the disease by handling infected dead animals and their products. Sporadic cases of human anthrax have been reported from Southern India. Methods: Five tribal men presented with painless ulcers with vesiculation and edema of the surrounding skin on the extremities without any constitutional symptoms. There was a history of slaughtering and consumption of a dead goat ten days prior to the development of skin lesions. Clinically cutaneous anthrax was suspected and smears, swabs and punch biopsies were taken for culture and identification by polymerase chain reaction (PCR). All the cases were treated with intravenous followed by oral antibiotics. Appropriate health authorities were alerted and proper control measures were employed. Results: Smears from the cutaneous lesions of all five patients were positive for Bacillus anthracis and this was confirmed by a positive culture and PCR of the smears in four of the five cases. All the cases responded to antibiotics. Conclusion: We report five cases of cutaneous anthrax in a non-endemic district, Visakhapatnam, Andhra Pradesh, for the first time.

KeY Words: Cutaneous anthrax

\section{INTRODUCTION}

Anthrax is a disease of herbivorous animals caused by Bacillus anthracis, and humans incidentally acquire the disease by handling infected dead animals and their products. $^{[1-4]}$ Cutaneous anthrax is the commonest type; the other two, inhalational and gastrointestinal anthrax, are uncommon forms. Sporadic cases of cutaneous anthrax caused by biting flies have been reported. ${ }^{[5,6]}$

Anthrax is known to occur globally, and it has been estimated that as many as 20,000 to $1,00,000$ human cases of anthrax occur annually, generally in underdeveloped regions of the world, where livestock are not vaccinated..$^{[1,4,7]}$ The actual incidence of anthrax in India is not known accurately mostly due to underreporting..$^{[3,8]}$ Many regions in India are still enzootic for animal anthrax, but it is less frequent or absent in North India, and sporadic cases of human anthrax have been reported, especially from South India. ${ }^{[9]}$ According to a recent review of literature, there have been about 205 documented cases from India,

\footnotetext{
How to cite this article: Rao GRR, Padmaja J, Lalitha MK, Rao PVK, Gopal KVT, Kumar HKY, Mohanraj P. An outbreak of cutaneous anthrax in a non-endemic district - Visakhapatnam in Andhra Pradesh. Indian J Dermatol Venereol Leprol 2005;71:102-5.

Received: October, 2004. Accepted: November, 2004. Source of Support: Nil.
} 
the majority (109) of cutaneous anthrax. ${ }^{[8]}$

In Andhra Pradesh, Chittoor, Cuddapah, Guntur, Prakasam and Nellore districts are the known endemic areas for animal and human anthrax. ${ }^{[10,11]}$ According to the Department of Animal Husbandry, Govt. of Andhra Pradesh, there were 1220 animal anthrax outbreaks in Andhra Pradesh from 1991 to 2004, all in these districts. For the first time five cases of human cutaneous anthrax were identified in a remote tribal hamlet, Pedalabudu, in Araku valley mandal situated $140 \mathrm{~km}$ from Visakhapatnam, which is a non-endemic district of Andhra Pradesh. These cases prompted us to take up this detailed study.

\section{METHODS}

Five tribal men were brought with painless ulcers with surrounding vesiculation and edema on the extremities since ten days. They had no constitutional symptoms. Three weeks earlier one of their goats died of sudden illness and these people were involved in slaughtering, cooking and eating it. After 10 days, they started developing these skin lesions.

The clinical details of all the cases are given in Table 1. On the basis of the history of contact with an infected carcass and the characteristic clinical features (Figure 1) a diagnosis of cutaneous anthrax was made. All five patients were hospitalized and investigated. Smears and swabs taken from the vesicles, ulcers and fluid from the surrounding edematous region were Gram stained and cultured. Full thickness $4 \mathrm{~mm}$ punch biopsies were also taken in all the patients from the edge of the ulcers. Some smears, cultures and biopsies were sent to the Department of Clinical Microbiology, CMC, Vellore for confirmation of the diagnosis of anthrax by PCR. Routine blood and biochemical investigations and chest $\mathrm{X}$-ray were done in all patients.

All the patients were treated with intravenous ciprofloxacin $400 \mathrm{mg}$ 12-hourly along with $500 \mathrm{mg}$ ampicillin 8-hourly for the first five days, followed by oral ciprofloxacin $500 \mathrm{mg}$ twice a day and ampicillin $500 \mathrm{mg}$ 8-hourly for two weeks.

\section{RESULTS}

The direct smears of all the five suspected cases revealed thick Gram positive bacilli singly and in short chains (Figure 2). These findings were suggestive of Bacillus anthracis. Four out of five samples grew on blood agar non-hemolytic, large, irregular, raised, dull, opaque, grayish white coloured colonies with a frosted glass appearance, suggestive of Bacillus anthracis. Histopathology of the biopsy specimens showed foci of necrosis with marked congestion, hemorrhages and extensive neutrophilic infiltrates. Finally PCR was positive for the genes encoding the protective antigen (PA) and also capsular region (CAP), confirming Bacillus anthracis (Figure 3), in all patients.

Prompt clinical response to ciprofloxacin and ampicillin therapy was seen in all the five patients; improvement was seen in the form of reduction of surrounding edema within 5-7 days and eschar formation, followed by

\begin{tabular}{|c|c|c|c|c|c|}
\hline Cases & Age/sex & Site & Type of skin lesion & Associated features & Investigations \\
\hline Patient 1 & 29 years/male & $\begin{array}{l}\text { Dorsum of } \\
\text { right hand }\end{array}$ & $\begin{array}{l}\text { Painless bullous lesion with } \\
\text { central ulceration surrounded } \\
\text { by extensive edema }\end{array}$ & $\begin{array}{l}\text { Axillary lymphadenopathy } \\
\text { present }\end{array}$ & $\begin{array}{l}\text { Gram positive bacilli, } \\
\text { PCR positive }\end{array}$ \\
\hline Patient 2 & 45 years/ male & $\begin{array}{l}\text { Dorsum of } \\
\text { left hand }\end{array}$ & $\begin{array}{l}\text { Painless ulcerated lesion with } \\
\text { vesiculation surrounded with } \\
\text { massive edema }\end{array}$ & $\begin{array}{l}\text { Axillary lymphadenopathy } \\
\text { present }\end{array}$ & $\begin{array}{l}\text { Gram positive bacilli, } \\
\text { PCR positive }\end{array}$ \\
\hline Patient 3 & 35 years/ male & $\begin{array}{l}\text { Left ring and } \\
\text { index fingers }\end{array}$ & $\begin{array}{l}\text { Two painless ulcers } \\
\text { with vesiculation surrounded } \\
\text { by erythema and edema }\end{array}$ & No lymphadenopathy & $\begin{array}{l}\text { Gram positive bacilli, } \\
\text { PCR positive }\end{array}$ \\
\hline Patient 4 & 40 years/ male & Left palm & $\begin{array}{l}\text { Painless bullous lesion with } \\
\text { central ulceration with edema } \\
\text { of the left hand }\end{array}$ & No lymphadenopathy & $\begin{array}{l}\text { Gram positve bacilli, } \\
\text { PCR positive }\end{array}$ \\
\hline Patient 5 & 45 years/ male & $\begin{array}{l}\text { Dorsum of } \\
\text { right great toe }\end{array}$ & $\begin{array}{l}\text { Painless ulcer with crusting } \\
\text { and massive edema of } \\
\text { the right foot }\end{array}$ & Inguinal Lymphadenopathy & $\begin{array}{l}\text { Gram positive bacilli, } \\
\text { PCR positive }\end{array}$ \\
\hline
\end{tabular}




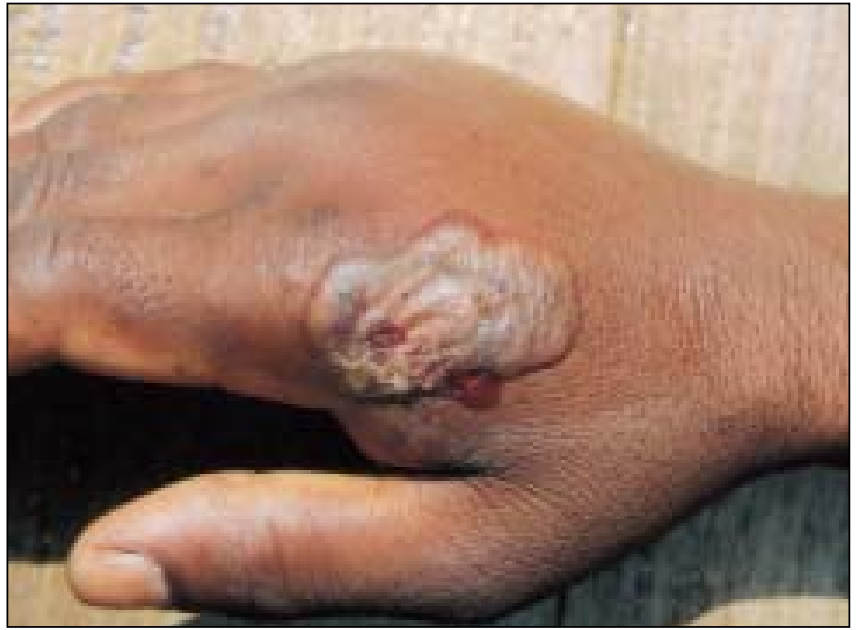

Figure 1: A bullous lesion with central ulceration and surrounding edema

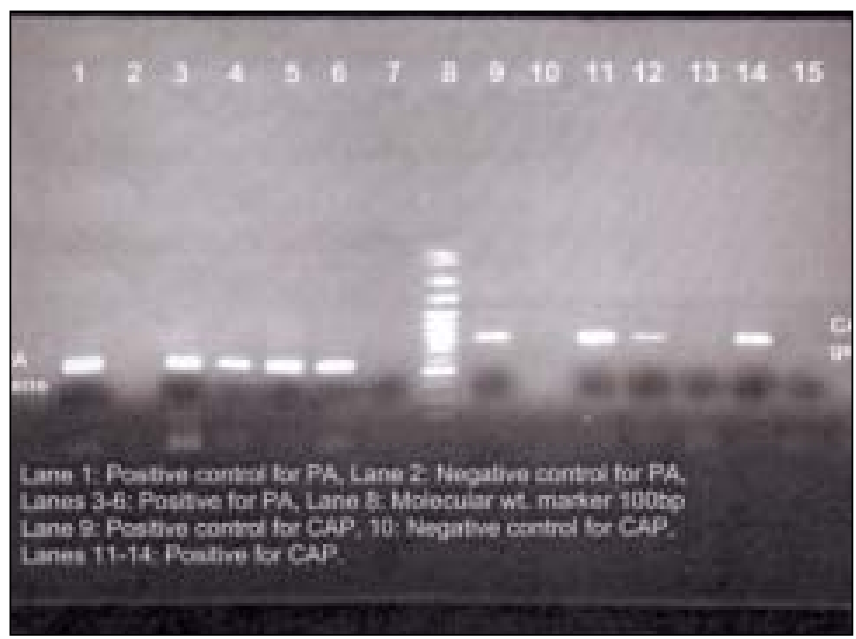

Figure 3: Agarose gel image of the PCR performed on smear from skin lesions

healing of the ulcers after two weeks (Figure 4).

\section{DISCUSSION}

Cases of cutaneous anthrax have not been frequently reported in India, though the disease is endemic in many parts of the country. ${ }^{[12]}$ Cutaneous anthrax accounts for $95 \%$ of all human anthrax cases. ${ }^{[1,4,7,13]}$ Unlike the other forms, inhalational and gastrointestinal anthrax, it is not a life threatening disease. Spontaneous healing occurs in $90 \%$ of cases. ${ }^{[7]}$ However, mortality in untreated cases of cutaneous anthrax is estimated to be $5-20 \% .{ }^{17]}$ The characteristic clinical features of cutaneous anthrax are a painless ulcer with surrounding vesiculation along with massive edema and eschar formation (malignant pustule). Mild constitutional

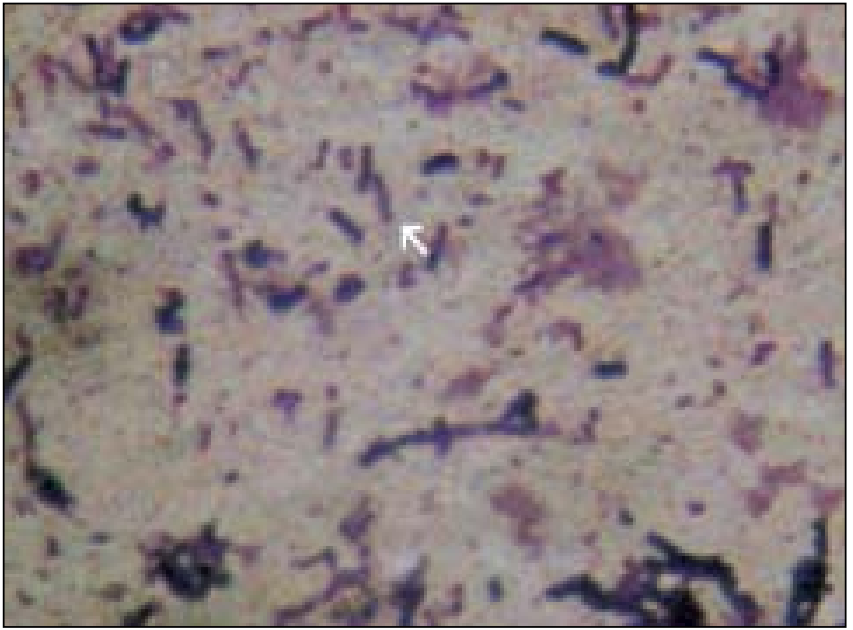

Figure 2: Smear from skin lesion: Gram positive bacilli singly and in short chains (Gram's, x1000)

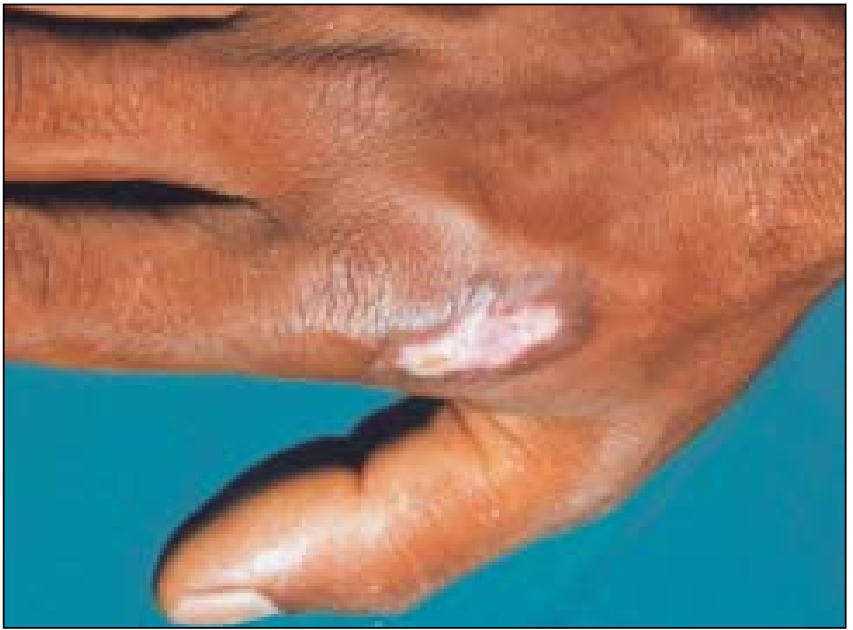

Figure 4: Healing of lesion with ciprofloxacin therapy

symptoms may be seen along with regional lymphadenopathy. These lesions are seen commonly on the face, neck and extremities. These features clinically differentiate the disease from other common infectious conditions like impetigo, cellulites, orf (ecthyma contagiosum), milker nodules etc. ${ }^{[1,4,7]}$

To diagnose cutaneous anthrax, a high index of clinical suspicion and a good history are essential. In our patients there was history of contact with a dead animal and the characteristic lesions were seen on the extremities. The laboratory diagnosis of cutaneous anthrax depends upon recognition of the thick, Gram positive bacilli in smears from the lesions. Cultures from the skin lesions however are not useful diagnostically because the rate of positive cultures does not exceed 
$60-65 \%$, probably due to the prior use of antimicrobial therapy or due to the microbicidal activity of local antagonistic skin flora. ${ }^{[1]}$ Therefore confirmation of cutaneous anthrax depends upon a positive PCR for Bacillus anthracis, ${ }^{[1,7,8,14,15]}$ even in patients who have received prior antimicrobial therapy. In all our five patients direct smears and PCR showed Bacillus anthracis, and in four the culture was positive, thereby confirming the diagnosis of cutaneous anthrax.

Though penicillin is the drug of choice for all forms of anthrax, beta-lactamase producing strains of $B$. anthracis have been reported. ${ }^{[6,16]}$ Therefore the American Academy of Dermatology recommends ciprofloxacin or doxycycline and one or two additional antimicrobials for all forms of anthrax. ${ }^{[17]}$ All our five cases responded dramatically to ciprofloxacin and ampicillin therapy and the lesions healed without scar formation.

Cutaneous anthrax occurs commonly in clusters or as an outbreak in endemic areas. Recently, three outbreaks of cutaneous anthrax similar to that of ours have been reported from Mysore (1999), Midnapore (2000) and Kolar (2001). ${ }^{[9]}$

Anthrax is a disease of public health importance and a notifiable disease. Once the diagnosis was established in our cases, the district health authorities and animal husbandry personnel were informed. Specialist teams visited the affected and the surrounding villages for door to door surveillance and for conducting medical camps to detect new cases. Nearly 1000 people were examined. Health education camps were conducted to educate the people about the handling of dead animals and also proper disposal of carcasses by using lime. In the affected and surrounding villages, sanitary measures were taken and the soil was decontaminated with bleaching powder. Animal husbandry authorities surveyed all the animals in these areas and found 6-8 animals suffering from anthrax (the diagnosis was established by smear and culture studies). Nearly 10,000 animals were vaccinated with live attenuated spore vaccine from Veterinary Biological Institute, Hyderabad, within a week of this outbreak under a mass vaccination program.

Dermatologists play a crucial role in the diagnosis of naturally occurring cutaneous anthrax and also in the event of bio-terrorism. The purpose of this report is to create awareness about cutaneous anthrax among dermatologists.

\section{REFERENCES}

1. Thappa DM, Karthikeyan K. Anthrax: An overview within the Indian subcontinent. Int J Dermatol 2001;40:216-22.

2. Hanna P. Anthrax pathogenesis and host response. Curr Trop Microbiol Immunol 1998;225:3-35.

3. Thappa DM, Karthikeyan K. Cutaneous Anthrax: An Indian Perspective. Indian J Dermatol Venereol Leprol 2002;68: 316-9.

4. Morton MS, Arnold NW. Miscellaneous Bacterial Infections with Cutaneous manifestations. In: Freedberg IM, Eisen AZ, Wolff K, Austen KF, Goldsmith LA, Katz SI, editors. Fitzpatrick's, Dermatology in General Medicine. $6^{\text {th }}$ Ed. New York: McGraw - Hill; 2003. p. 1918-21.

5. Turell MJ, Knudson GB. Mechanical transmission of Bacillus anthracis by stable flies (Stomoxys calcitrans) and mosquitoes (Aedes aegypti and Aedes taeniorhynchus). Infect Immun 1987;55:1859-61.

6. Bradaric N, Punda-Polic V. Cutaneous anthrax due to Penicillin resistant Bacillus anthracis transmitted by an insect bite. Lancet 1992;340:306-7.

7. Wenner KA, Kenner JR. Anthrax. Dermatol Clin 2004:22; 247-56.

8. Lalitha MK. Human Anthrax: Experience over two decades. Round Table Conference Series Number 9. New Delhi, India: Ranbaxy Science Foundation; 2001. p. 51-7.

9. Dutta KK. Emergence of anthrax as an agent of Bio - terrorism. Round Table Conference Series Number 9. New Delhi, India: Ranbaxy Science Foundation; 2001. p. 11-20.

10. Sekhar PC, Singh RS, Sridhar MS, Bhaskar CJ, Rao YS. Outbreak of human anthrax in Ramabhadrapuram Village of Chittor District of Andhra Pradesh. Indian J Med Res 1990;91:448-52.

11. Sridhar MS, Chandrasekhar P, Singh J, Jayabhaskar C. Cutaneous Anthrax with Secondary Infection. Indian J Dermatol Venereol Leprol 1991;57:38-40.

12. Lalitha MK, Kumar A. Anthrax - A continuing problem in southern India. Indian J Med Microbiol 1996;14:63-72.

13. Taylor JP, Dimmitt DC, Ezzell JW, Whitford H. Indigenous human cutaneous anthrax in Texas. South Med J 1993;86:1-4.

14. Hutson RA, Duggleby CJ, Lowe JR, Manchee RJ, Turnbull PC. The Development and assessment of DNA oligonucleotide probes for the specific detection of Bacillus anthracis. J Appl Bacteriol 1993;75:463-72.

15. Bhatra HV. Biology and Laboratory Diagnosis of Anthrax. Round Table Conference Series Number 9. New Delhi, India: Ranbaxy Science Foundation; 2001. p. 31-40.

16. Lalitha MK, Thomas MK. Penicillin resistance in Bacillus anthracis. Lancet 1997;349:1552.

17. John AC, Thomas WM, Scott AN, Ralph Daniel, Bony EE, Sheila FF, et al. Cutaneous anthrax management algorithm. J Am Acad Dermatol 2002;47:766-9. 